\title{
Analysis Of Acute Respiratory Infection Trends in the High-risk Zone of Exposure to Coal Dust in Meulaboh
}

\author{
Enda Silvia Putri ${ }^{1^{*}}$, Susy Sriwahyuni ${ }^{2}$ \\ ${ }^{1}$ Nutrition Department Faculty of Public Health Universitas Teuku Umar, Komplek Kampus Universitas Teuku Umar Alue \\ Peunyareng Meulaboh Aceh Barat, Aceh 23681, Indonesia \\ ${ }^{2}$ Public Health Department Faculty of Public Health Universitas Teuku Umar, Komplek Kampus Universitas Teuku Umar \\ Alue Peunyareng Meulaboh Aceh Barat, Aceh 23681, Indonesia \\ *Corresponding Author: endasilviaputri@utu.ac.id, endasilvia17@gmail.com, Phone:+62-85-277365563
}

Info Artikel:Diterima 15 Februari 2021 ; Direvisi 2 November 2021 ; Disetujui 4 November 2021

Tersedia online : 4 Februari 2022 ; Diterbitkan secara teratur : Februari 2022

Cara sitasi (Vancouver): Putri ES, Sriwahyuni S. Analysis Of Acute Respiratory Infection Trends in the High-risk Zone of Exposure to Coal Dust in Meulaboh. Jurnal Kesehatan Lingkungan Indonesia [Online]. 2022 Feb;21(1):34-42. https://doi.org/10.14710/jkli.21.1.34-42.

\begin{abstract}
ABSTRAK
Judul : Analisis Tren Infeksi Saluran Pernapasan Akut Pada Zona Wilayah Risiko Tinggi Paparan Debu Batubara di Meulaboh

Latar Belakang : Pertumbuhan dua industry (PT. Mifa Bersaudara Meulaboh dan Pembangkit Listrik Tenaga Uap Nagan Raya) dapat berkorelasi negative dengan tren kasus ISPA. Berdasarkan data kasus dari dua Puskesmas yang merupakan Puskesmas yang berada pada wilayah berdirinya dua perusahaan tersebut terjadi peningkatan kasus ISPA setiap tahunya. Penelitian ini bertujuan meneliti analisis tren ISPA pada zona wilayah risiko tinggi paparan debu batubara PT. Mifa Bersaudara Meulaboh dan Pembangkit Listrik Tenaga Uap Nagan Raya.

Metode : Metode penelitian ini dengan mengkombinasi desain case control dan fenomologi, sampel penelitian ini berjumlah 100 orang masyarakat yang berdomisili $(0-50 \mathrm{~km})$ dari perusahaan, dan dengan teknik pengambilan sample purposive random sampling. Analisis data mengunakan uji chi-square dan wawancara mendalam.

Hasil : Hasil penelitian menunjukan terjadi tren kasus ISPA sebesar 1\% setiap tahunnya, terdapat hubungan kecurigaan paparan debu dan asap batubara dari kedua perusahaan tersebut terhadap gejala ispa pada masyarakat dengan risiko ISPA 13 kali pada zona wilayah risiko tinggi paparan debu batubara $(P$ value $<$ $0.0001, O R=13.037$ ).

Simpulan : Terdapat perbedaan yang signifika yang dirasakan masyarakat dari sebelum dan seudah berdirinya dua perusahaan tersebut terutama terkait keluhan gangguan pernapasan, keluhan kondisi lingkungan yang menurun (polusi udara dan tercemarnya tanah), serta kurangnya perhatian perusahaan terhadap penanggualangan dan pencegahan efek yang akan ditimbulkan.

Kata kunci: Batubara; Debu; Asap; ISPA

\section{ABSTRACT}

Introduction: The growth of two industries (such as PT. Mifa Bersaudara Meulaboh and Steam Power Plant Nagan Raya) can be negatively correlated with the trend of ARI cases. Based on data, cases from two Public Health Centers which are located around both the companies showed an increase in cases of ARI annually. This research aims to analyze ARI trends in the high risk zone of exposure to coal dust PT. Mifa Bersaudara Meulaboh and Steam Power Plant Nagan Raya.
\end{abstract}


Method : The method of this research combined design of case control and fenomology. The sample was as much as 100 people who live $(0-50 \mathrm{~km})$ from the company, and technique sampling used purposive random sampling. Data analysis used the chi-square test and in-depth interviews.

Result : The results found that there was trend of ARI cases as many as $1 \%$ each year. There was a suspicion relationship between exposure to fumes and coal dust from the two companies on symptoms of ARI in the community with the risk of ARI 13 times in the zone of high risk of exposure to coal dust (p value $<0.0001$, OR =13.037).

Conlusion: There was a significant difference felt of the society both before and after the establishment of the two companies, mainly related to complaints of respiratory problems, degradation of environment condition such as air pollution and soil contamination as well as the company's lack of attention to cope with and prevent of its effects that will be caused.

Keywords: Coal; Dust; Fumes; ARI

\section{INTRODUCTION}

West Aceh and Nagan Raya districts are located in the south west coast of Aceh. These districts were hit by the tsunami of Aceh in 2004. After the tsunami, however, they continually showed a development in the economic and development sectors. After the tsunami, reconstruction and development could be said to be fast, including in the industrial sector, for instance, West Aceh district which had planned from 2002 before the tsunami, the establishment of PT Mifa Bersaudara with evidence of the Deed of Incorporation of PT No. 69/12 January 2002, and has been ratified by the Decree of the Minister of Law and Human Rights of the Republic of Indonesia No. C03647.HT.01.01.TH.2002 concerning Ratification of the Deed of incorporation of PT. The company is a subsidiary of PT Media Djaya Bersama, which operates in West Aceh, Aceh Province. The company is engaged in coal mining. It can be seen that its active activity is approximately ten years after the tsunami with the Production Operation Mining Business Permit (IUP-OP) No.117b / 2011 on behalf of PT Mifa Bersaudara which has a concession area of 3,134 hectares $(\mathrm{Ha})$ in the West Aceh region that has received a Clean Certificate and Clear $(\mathrm{CnC})$ Number: 234 / Bb / 03/2014(1).

PT. PLN (Persero) Nagan Raya Sector Power Plant was the forerunner of PLTU Nagan Raya with the construction of a 10,000 MW project assigned by the government to PT. PLN (Persero) in 2006 according to Presidential Decree no. 17 (5 July 2006). This project was located in Suak Puntong Village, Kuala Pesisir District, Nagan Raya Regency. At the end of 2011 ahead of commercial plans, the new President Director of PT-PLN will establish an electricity center under PT. PLN (Persero) North Sumatra (2)

Subsequent decisions by the board of directors emerged on June 2012 which transformed the Nagan Raya electricity center into the Nagan Raya sector and the lueng bata sector into an electricity center in accordance with DIR Decree No. 285.k / DIR / 2012 and No. 287.k / DIR / 2012, at the time of the change in status. PT. PLN (Persero) Lueng Bata generation sector has just received the transfer of PLTD leased on the $150 \mathrm{KV}$ Grid from PT PLN (Persero) Aceh region in the process of the transition period from $\mathrm{PT}$. PLN in the Lueng Bata sector to be PT. PLN Nagan Raya sector which has transferred assets back from PT PLN (Persero) Aceh region to PT. PLN (Persero) KITSBU so that there are two more locations, such as PLTD Pulo Banana and Cot Trueng (2).

The growth of these two can have a positive impact in terms of job opportunities. This positive impact also coincides with the negative impact that can be caused by the two industries, related to the waste like that : smoke and dust produced by these companies, although there has been no significant research in analyzing these problems in the area where the two companies were founded (3-5).

In other areas where Steam of Power Palnts permits have been granted and coal mining companies based on research results have proven a relationship between smoke or dust from coal combustion and cases of hoarseness (including ARI). The results of research conducted by Juniah in 2013 stated that coal mining has an impact on public health, especially ARI. It was stated that there was a change in lung function due to exposure to coal dust. Exposure to coal dust causes the lungs to blacken (6-8).

Therefore, researchers were interested in conducting research related to the negative impacts that may be caused by waste, such as smoke and dust from these two companies. The focus of the study was to determine the trend of increasing cases of ARI in the high risk zone of exposure to coal dust and smoke from PT Mifa Bersaudara from PLTU Nagan Raya. This case was interesting to study from the ARI data collected from the Meureubo and Padang Rubek Health Centers, which were a public health centers whose working areas were the areas where the two companies were founded. Cases of ARI in Meureubo and Padang Rubek Health Centers tend to increase every year after the active industrial operations of the two companies. Average ARI case data were 2012: 3779, 2013: 3800, 2014: 3825, 2015: 3905, 2016: 3924, 2017: 3941. Most ARI cases were suffered by high-risk groups, especially children. Case data were collected based on patients who were residents of the Puskesmas working area whose settlements were in 
two industrial areas (Meureubo and Padang Rubek Health Center Data System Centers) (9).

Based on the problems above, it was very important that this study was conducted because it aims to analyze the trend of increasing cases of ARI in the high risk zone of exposure to coal dust from PT Mifa Ber Saudara and the smoke from the PLTU Nagan Raya. This research was expected to provide evaluation material for the two companies to be able to control the industrial waste generated if it is suspected to have an effect on the ARI cases that occur. For the community, they were able to take preventive action as early as possible against the impact of industrial waste. The objective of this research was to develop an evaluation process for waste disposal in the company and from the awareness and understanding of the community regarding the factors that affect health (especially lung health).

\section{MATERI AND METHOD}

The research method was combines qualitative research methods (phenomenological design) and quantitative research methods (case control/retrospective design).

The phenomenological design was used to capture the problem by means of in-depth interviews using interview guidelines for community groups who were in high risk zones exposed to PLTU smoke and PT Mifa Bersaudara coal dust. Case control design was used to capture problems through interviews using questionnaires to case and control community groups (heads of families) who were in a high risk zone and not exposed to PLTU smoke and coal dust, so that it can be seen backwards whether the suspected ARI symptoms were closely related to exposure to smoke and dust coal $(10,11)$.
The zone targeted for the case was $0-20 \mathrm{~km}$ of north and south of Steam Power Plant Nagan Raya and PT. Mifa Bersaudara assumed a high risk exposure area with a sample size (50 people from the head of the family). Mifa Bersaudara, while the zone targeted for control was 21-50 km north and south of Steam Power Plant Nagan Raya and PT. Mifa Bersaudara with the assumption that it was not a highrisk area for exposure (50 people from the head of the family). Samples were taken by non-random sampling technique, such as purposive sampling. The total sample was 100 consisting of 50 cases and 50 controls.

Primary data was the result of questionnaire data processing. The data was then processed using SPSS for Windows Realease 20. The data were analyzed using the comparative hyphotesis test of two groups of categorical variables, namely the Chi Square Test.

\section{RESULTS AND DISCUSSION Analysis Of Ari Trend Based On Case Data At Public Health Center}

The results showed that the description of ARI cases was based on secondary data obtained from the Meureubo Health Center, Meureubo District, West Aceh Regency and Padang Rubek Health Center, Kuala Pesisir District, Nagan Raya Regency, which were two health centers located in the high risk zone of exposure to coal dust from PT Mifa Bersaudara and exposure to coal smoke from the Steam Power Plant (PLTU).

The results of the secondary data that the researchers got the ARI case data from the Meurebo Community Health Center which was located in the zone where PT Mifa Bersaudara was founded could be showed in Figure 1.

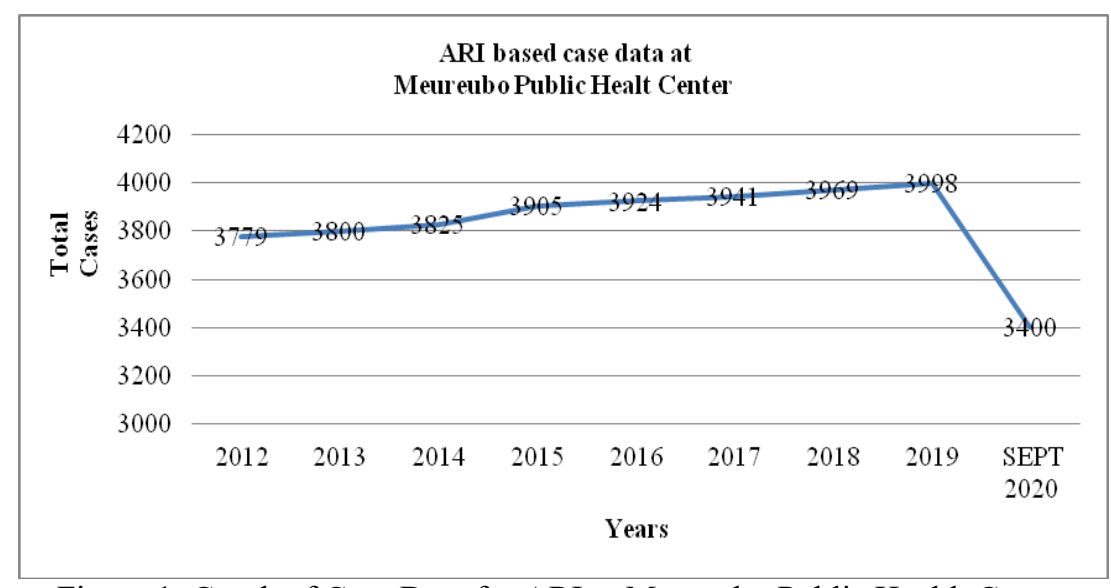

Figure 1. Graph of Case Data for ARI at Meureubo Public Health Center

The Figure 1 depicts that there has been an increase in case data every year from 2012 to 2019 and it can be predicted in 2020 having a rise as the data accumulated until September 2020 alone has reached 3400 cases.
Based on interviews with data holders, researchers also did not get complete data on ARI cases such as characteristics (age, gender, address, etc.) and causes. This was because the data holders only received the results of the case data summaries from all program holders. The available data was only able to see the 
number of cases per year. So it was difficult for researchers to describe the causes of ARI due to coal dust / steam power plant or not based on data from the Meureubo Public Health Center. The data of program holders could no longer be seen since after the recapitulation and submission to the data holder, the data was immediately stored and difficult to see again.
The results of secondary data that the researchers collected the case data for ARI from the Padang Rubek Public Health Center, which was in the zone of the steam power plant establishment, could be shown by researchers in Figures 2 and 3.

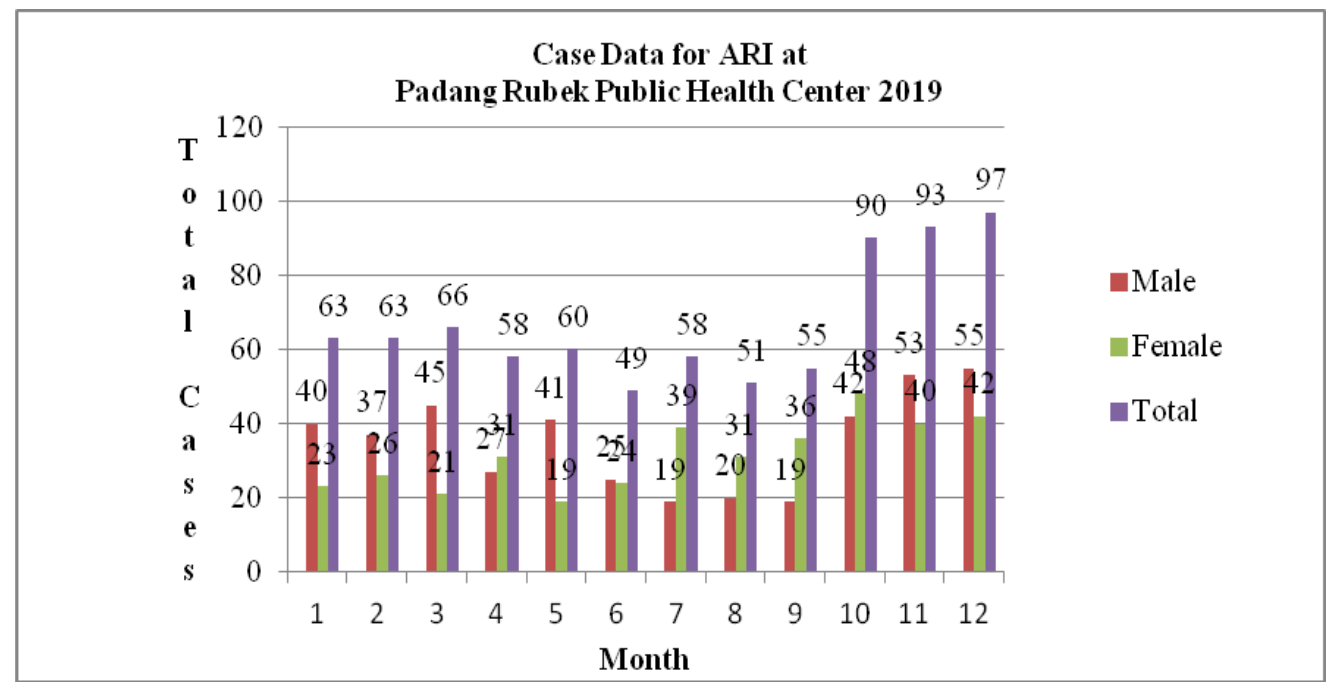

Figure 2. Graph of Case Data for ARI at Padang Rubek Public Health Center 2019

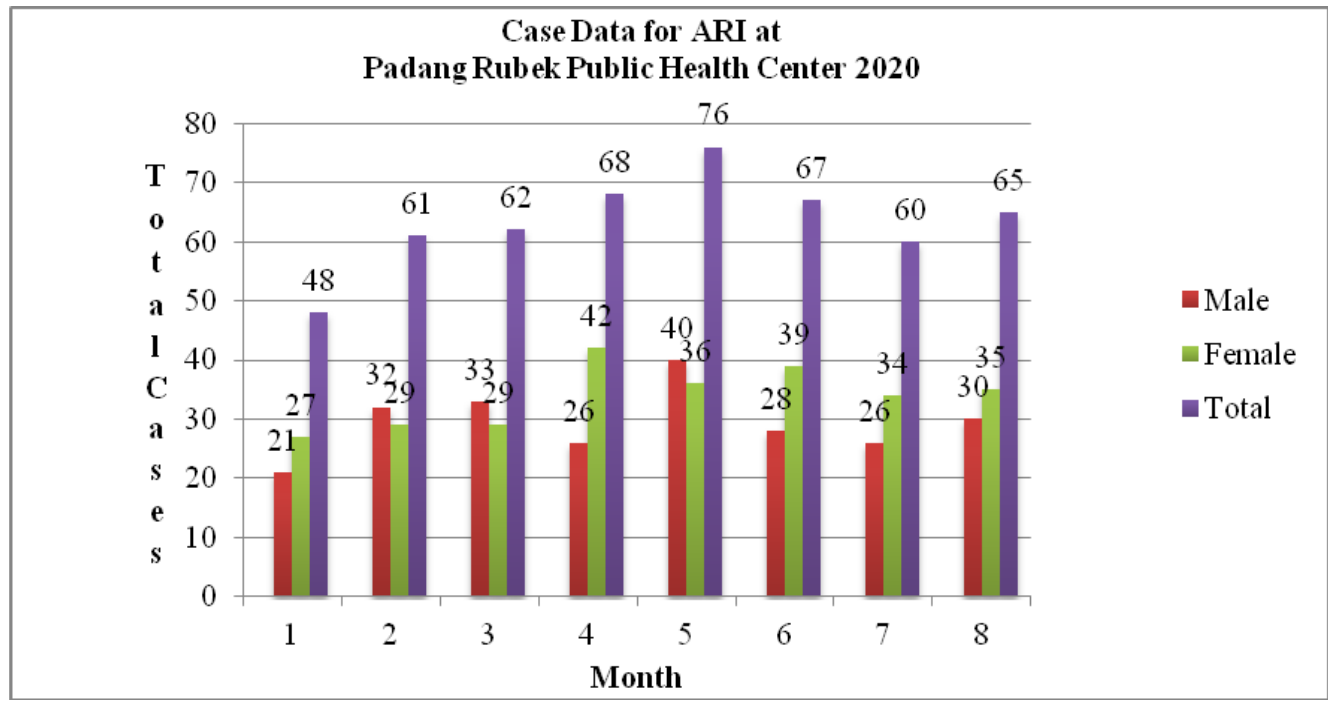

Figure 3. Graph of Case Data for ARI at Padang Rubek Public Health Center 2020

The Figures 2 and 3 show that the ARI case data at the Padang Rubek Health Center in 2019 and 2020 was very volatile and the average case data every year was more than 50 cases. Researchers only obtained case data for 2019 and 2020, the reason for the insufficient data obtained at the Padang Rubek Public Health Center is almost similar to the Meureubo Public Health Center. In the case data for ARI cases at the Padang Rubek Public Health Center, researchers could only see the distribution of case data based on gender and age for two years and could not see other characteristics. The results of this case data are only able to see the alleged high number of ARI cases due to Steam Power Palnts smoke.
The primary data in this study were obtained by interviewing 50 heads of case families with the assumption that the area was at high risk of exposure to smoke and coal dust, namely those whose residences were $0-20 \mathrm{KM}$ from the industry and the control group was 50 heads of households with a house distance of 21-50 KM.

The results of primary data collection were obtained from 100 samples who were respondents from Peunga Cut Ujong Village: 25 people were from high risk zone villages $(0-20 \mathrm{~km})$ exposed to coal dust from PT Mifa Brothers and were residents of Peunaga Paya village: 25 people were not the high risk zone $(21-50 \mathrm{~km})$ of PT Mifa Brothers dust exposure was 
also the working area of the Meureubo Community Health Center village. Residents of Suak Puntong Village: 25 people were from high risk zone villages (0-20 km) exposed to PLTU coal smoke, Kuala Baroe Village residents: 25 people were villages not high risk zone $(21-50 \mathrm{~km})$ exposed to PLTU coal smoke which was also an area Padang Rubek Health Center work.

The results of the univariate analysis based on questionnaire questions interviewed by field officers were as follows.

Table 1. Frequency Distribution of Questionnaire Results

\begin{tabular}{|c|c|c|}
\hline Variable & Frequency & Percent \\
\hline \multicolumn{3}{|l|}{ Age } \\
\hline $15-19$ & 4 & 4 \\
\hline $20-24$ & 4 & 4 \\
\hline $25-29$ & 12 & 12 \\
\hline 30-34 & 17 & 17 \\
\hline 35-39 & 11 & 11 \\
\hline $40-44$ & 13 & 13 \\
\hline $45-49$ & 14 & 14 \\
\hline $50-54$ & 10 & 10 \\
\hline $55-59$ & 3 & 3 \\
\hline $60-64$ & 7 & 7 \\
\hline $65-69$ & 2 & 2 \\
\hline $70-74$ & 2 & 2 \\
\hline $75-79$ & 0 & 0 \\
\hline 80-84 & 1 & 1 \\
\hline \multicolumn{3}{|l|}{ Sex } \\
\hline Male & 32 & 32 \\
\hline Female & 68 & 68 \\
\hline Total & 100 & 100 \\
\hline \multicolumn{3}{|l|}{ ARI } \\
\hline Yes & 12 & 12 \\
\hline No & 88 & 88 \\
\hline Total & 100 & 100 \\
\hline \multicolumn{3}{|c|}{ Symptoms ARI } \\
\hline Yes & 62 & 62 \\
\hline No & 38 & 38 \\
\hline Total & 100 & 100 \\
\hline \multicolumn{3}{|c|}{ Masks Before Symptoms ARI } \\
\hline Yes & 0 & 0 \\
\hline No & 100 & 100 \\
\hline Total & 100 & 100 \\
\hline \multicolumn{3}{|c|}{ Masks After Symptoms ARI } \\
\hline Yes & 3 & 3 \\
\hline No & 97 & 97 \\
\hline Total & 100 & 100 \\
\hline \multicolumn{3}{|c|}{$\begin{array}{l}\text { Suspicion of ARI Due to } \\
\text { Exposure to Coal Dust PT. }\end{array}$} \\
\hline \multicolumn{3}{|c|}{ Raya } \\
\hline Yes & 62 & 62 \\
\hline No & 38 & 38 \\
\hline Total & 100 & 100 \\
\hline \multicolumn{3}{|c|}{$\begin{array}{c}\text { Counseling on prevention of } \\
\text { ARI due to fume by Steam } \\
\text { Power Plant }\end{array}$} \\
\hline Yes & 1 & 1 \\
\hline No & 99 & 99 \\
\hline Total & 100 & 100 \\
\hline
\end{tabular}


Based on Table 1, it can be seen that the highest percentage of age was at the age of 45 years : $14 \%$, the highest gender was female : $68 \%$, the highest disease status did not experience ARI; 88\%, the highest status had experienced ARI symptoms : $62 \%$, did not use masks by the community before experiencing ARI symptoms, the highest was 100\%, and after experiencing ARI symptoms as much as $97 \%$, people suspected that the incidence of ARI symptoms suffered from coal dust and smoke from PLTU the highest of $62 \%$. PT Mifa Brothers and PLTU also have the highest points for not conducting preventive education at $100 \%$.

Based on Table 1. It can be seen that of the 100 interviewees, $32 \%$ did not experience ARI symptoms, and $68 \%$ experienced ARI symptoms. This could be an initial assumption that the case of ARI occurred due to exposure to dust and coal smoke from both industries. Researchers have not been able to relate the above allegations to the doctor's diagnosis of ARI patient cases from the Public Health Center because at the ublic Health Center there was still insufficient data related to the direct causes of positive cases of ARI caused by coal dust and smoke from PLTU. It was also necessary to carry out further research by conducting lung examinations using special tools in high-risk communities so that they can confirm the suspicion of ARI due to dust and smoke or not. It is very important to carry out counseling from PT Mifa Bersaudara and Steam Power Plants as industries that produce waste that has an impact on health, especially the problem of ARI cases, so far the two industries were still very less doing preventive efforts to the community as seen by the many people who experience ARI symptoms such as coughs and flu that can cause infection. It was suspected that it was due to inhalation of coal dust and steam from the steam power plant because people rarely used masks when doing activities and were constantly exposed to dust and smoke.

In the bivariate analysis, the researchers saw the relationship between ARI symptoms and the public's suspicion of exposure to coal dust and fumes of Steam Power Plant that caused the symptoms of ARI they experienced.

Table 2. Corelation Symptoms ARI with Suspicion of ARI Due to Exposere to Coal Dust of Industry

\begin{tabular}{|c|c|c|c|c|c|c|c|c|}
\hline \multirow{3}{*}{$\begin{array}{l}\text { Suspicion of ARI Due to } \\
\text { Exposure to Coal Dust } \\
\text { PT. Mifa and Fumes of } \\
\text { Steam Power Plant } \\
\text { Nagan Raya }\end{array}$} & \multicolumn{6}{|c|}{ Symptoms ARI } & \multirow[t]{2}{*}{ P Value } & \multirow{2}{*}{$\begin{array}{c}\text { OR } \\
(95 \% \mathrm{CI})\end{array}$} \\
\hline & \multicolumn{2}{|c|}{ Cases } & \multicolumn{2}{|c|}{ Control } & \multicolumn{2}{|c|}{ Total } & & \\
\hline & $\mathbf{n}$ & $\%$ & $\mathbf{N}$ & $\%$ & $\mathbf{n}$ & $\%$ & 0.000 & $\begin{array}{c}13.037 \\
(4.654-36.520)\end{array}$ \\
\hline Yes & 44 & 88 & 18 & 36 & 62 & 62 & & \\
\hline No & 6 & 12 & 32 & 64 & 38 & 38 & & \\
\hline Total & 0 & 100 & 50 & 100 & 100 & 100 & & \\
\hline
\end{tabular}

In Table 2, we can read that the results of the analysis show the relationship between ARI symptoms and exposure to coal smoke and dust from both industries with a $\mathrm{P}$ Value $<0.0001$, and in the high zone area, exposure to coal dust and smoke (0-20 $\mathrm{Km})$ was 13 times more at risk of ARI symptoms. /ARI compared to no zone of high exposure to dust and coal smoke $(21-50 \mathrm{Km})$ as evidenced by the results of statistical analysis with an odds ratio of $13,037,95 \%$ CI $(4,654-36,520)$.

Based on the results of in-depth interviews with the respondents, they said that since the two companies were established in their village, they have received many health complaints and complaints about environmental conditions. They usually experience health complaints such as coughs and flu, if the cough is so severe that it interferes with their activities, then they go for treatment to health services such as Public Health Center. Public Health centers have limited tools in detecting the cause of the ARI symptoms, so the doctor's diagnosis cannot confirm the ARI symptoms due to exposure to dust and coal smoke. Respondents also complained about environmental conditions such as the condition of their soil and plants that were no longer as fertile as before due to the high air pollution in the area. Respondents also said that companies rarely provide information on prevention efforts to residents and provide solutions to the impact of pollutants caused by their company activities, small examples such as providing masks and educating residents about the importance of using masks in areas with high risk of exposure to coal dust, repairs, and waste evaluation. the results of industrial activities on the environmental impacts caused.

Based on the results of secondary data analysis from two Public Health Center (Public Health Center of Meureubo and Padang Rubek) it was found that there was an increase in the trend of ARI cases by $1 \%$ from 2012 to 2020, the two Public Health Center were also Public Health Center located in the area where the two companies were founded, it is very likely The high number of ARI cases was due to exposure to coal dust and smoke from the two companies. Based on the univariate results obtained from the primary data analysis of 100 respondents (heads of families who live $0-50 \mathrm{~km}$ from the industry) using a questionnaire, it was found that $62 \%$ experienced ARI 
symptoms. The high percentage who experienced ARI symptoms compared to those that could not be corroborated also by the results of bivariate analysis which showed a relationship between ARI symptoms and exposure to coal dust and smoke with a value (P value $=0.000)$ and the risk was 13 times experiencing ARI symptoms. The risk was quite high in the high risk zone of exposure to coal smoke and dust, if the pollutant results were not immediately evaluated, it will have an impact not only on the symptoms of ARI/ARI, it can even cause lung cancer in people in high risk areas of exposure to coal dust and smoke (020). $\mathrm{Km}$ ), So that there must be serious handling from the company, especially in terms of prevention by encouraging the public to use masks and evaluating the company's waste disposal installations with pollutant indicators that do not exceed the threshold value, as well as stakeholder concern in the form of policies to industry and the community so that it was expected does not increase cases of ARI, environmental damage, and even prevent lung cancer in the future.

Based on the result of the research, it showed that the symptoms of ARI/ARI case were high in the 0-20 $\mathrm{Km}$ area, which was zone high-risk of exposure to coal dust and smoke, this was because the people of the area were often exposed to and inhaled coal smoke and dust. Comtinous exposure to coal dust/smoke not only has an impact on the upper ARI, it also has an impact on the lower ARI and even lung cancer.

The results obtained by researchers were also supported by several research results in several cities in Indonesia that carry out coal industrial activities such as Steam Power Plants and coal mining also have a negative impact from the waste produced by the industry on the environment and their health, people living around the industry experience health problems. such as ARI and their environment are polluted by pollutants, both containing carcinogenic substances and those without carcinogenic substances, and based on the results of research, it has been proven to have an impact on the respiratory tract $(12,13)$.

Raharjo's research, 2016 titled analysis of public communication responses on the impact of coal stockpiles stateed that: 1) there was a difference in the degree of community response based on the size of the impact received from coal dust. 2) The response of the people who lived near the stockpile and the wind direction factor had a relatively higher rejection response than other residential locations. 3) Most of the respondents stated that stockpile activities disturb public health and comfort. 4) It turned out that only a small proportion of respondents had ever submitted their complaints to the company and the Bandar Lampung city government. Maryuningsih (2015) in the results of his research stated that the activities of the Coal Stockpile Industry had an impact on the Environment and Health Level of the People of the Coastal Village of Rawaurip, Kec. Pangenan Kab. Cirebon. Khairiah 2012 stated that the activities of the
Cement Factory which use coal as fuel had caused health and environmental impacts on the surrounding community such as itching and bad air conditions so that it needed serious handling for the company to suppress waste residues and the community must plant plants that could absorb the dust. Research by Sukana (2013) found that people who were exposed to ARI were higher in people who lived in areas close to mining than those who were not due to frequent exposure to coal dust(14-17).

Although this study has not been able to confirm a strong relationship based on the results of a doctor's diagnosis and examination of residues of smoke and coal dust in the respiratory tract of respondents, the suspicion of exposure to coal dust and smoke with the incidence of ARI based on the results of a questionnaire that was corroborated with statistical results showed a relationship with a retrospective study design. It was also corroborated by many studies which state that there was a close relationship between exposure to dust and inhaled coal smoke with lung failure and causing ARI. Several Researchs were results a relationship between exposure to coal dust/smoke and the incidence of ARI in a person (1821).

Based on research from various countries that have industrial activities related to coal and produce waste (coal smoke and dust) it was found that exposure to new rock dust/smoke was very closely related, especially those that were frequently exposed, so that a person would be susceptible to ARI as researched from several countries (USA, Virginia, Africa, China, etc) $(22-31)$.

\section{CONCLUSION}

Based on the results of the study, it can be concluded that: There is an increase in the trend of ARI cases every year by $1 \%$. There is a relationship between suspected exposure to coal smoke and dust with ARI symptoms at the value of $\mathrm{P}=0.000$. Based on the results of in-depth interviews, the community claimed to experience health complaints (such as respiratory problems and eye irritation) or complaints about poor environmental conditions (air, soil) due to the impact of coal dust and smoke. There is still a lack of preventive counseling from the company, the reluctance of the community to submit complaints to the company, health workers, and community leaders regarding complaints of health problems and environmental pollution.

\section{REFERENCES}

1. PT Mifa Bersaudara. Ikhtisar [Internet]. Meulaboh: PT. Mifa Bersaudara. 2019. Available from: http://www.mifacoal.co.id/idid/TENTANG-KAMI/Ikhtisar

2. Raya PN. Sejarah PLTU Nagan Raya. 2014;

3. Putri ES. Survey Lapangan : PLTU Nagan Raya Pekerjakan 236 Putra Aceh. 2013.

4. Bahri S, Putri ES. Survey Lapangan: Limbah 
PLTU Diduga Cemari Saluran Air. 2019;

5. Putri ES. Survey Lapangan: Limbah PLTU Nagan Diduga Cemari Saluran Air Warga. 2019;

6. Juniah R, Dalimi R, Suparmoko M, Moersidik SS. Public health impact of coal mining among community living in coal mining area (review on environmental benefits to absorb carbon). J Ekol Kesehat. 2013;12(01):252-8.

7. Jie Y, Houjin H, Xun M, Kebin L, Xuesong Y, Jie X. Relationship between pulmonary function and indoor air pollution from coal combustion among adult residents in an inner-city area of southwest China. Brazilian J Med Biol Res [Internet]. 2014 Sep 23;47(11):982-9. Available from:

http://doi.org/10.1590/1414431X20144084

8. Sarver E, Keles C, Rezaee M. Characteristics of respirable dust in eight appalachian coal mines: A dataset including particle size and mineralogy distributions, and metal and trace element mass concentrations. Data $\mathrm{Br}$ [Internet]. 2019;25:104032. Available from: https://doi.org/10.1016/j.dib.2019.104032

9. Puskesmas Meureubo. Data SIMPUS UPTD Puskesmas Meureubo 2017. Meulaboh; 2018.

10. Sulistyaningsih. Metodologi Penelitian Kebidanan:Kuantitatif-Kualitatif. Metodologi Penelitian Kebidanan:Kuantitif-Kualitatif. 2011.

11. Sugiyono. Metodologi Penelitian Kuantitatif, Kualitatif, dan R\&D. CV Alfabeta. 2016.

12. Nggeboe F. Dampak sosial ekonomi penambangan batubara. psdk.wordpress.com [Internet]. 2009;43-51. Available from: http://psdk.wordpress.com/2009/04/06/bahayalimbah-cair- pertambangan-batubara/

13. Bahri S. Dampak Kesehatan dan Lingkungan Emisi Debu Dari Aktivitas PLTU Karangkandri Cilacap. J Rekayasa Teknol Ind Hijau [Internet]. 2018;3(1):1-9. Available from: https://ejournal.unugha.ac.id/index.php/ratih/arti cle/view/91/71

14. Raharjo TB. Analisis respon komunikasi masyarakat pada dampak stocpile batu bara. Pros Semin Nssional Komun 2016. 2016;415-26.

15. Maryuningsih Y. Analisis dampak industri stockpile batu bara terhadap lingkungan dan tingkat kesehatan masyarakat desa pesisir rawaurip kec. pangenan kab. cirebon. Sci Educ [Internet]. 2015;4(2). Available from: https://doi.org/10.24235/sc.educatia.v4i2.490

16. Khairiah, Ashar T, Santi DN. Analisis konsentrasi debu dan keluhan kesehatan pada masyarakat di sekitar pabrik semen di desa kuala indah kecamatan sei suka kabupaten batu bara tahun 2012. 2018;(May):1-7.

17. Sukana B, Lestary H, Hananto M. Kajian kasus ispa pada lingkungan pertambangan batu bara di kabupaten muara enim, sumatera selatan. J Ekol Kesehat. 2013;12(3):234-42.

18. Rahayu Simanjuntak NS, Suwondo A, Wahyuni
I. Hubungan antara kadar debu batubara total dan terhirup serta karakteristik individu dengan gangguan fungsi paru pada pekerja di lokasi coal yard pltu $\mathrm{x}$ jepara. J Kesehat Masy Univ Diponegoro. 2013;2(2):18705.

19. Wahyuni A, Rahim MR, Arsyad DS, Selomo M, Keselamatan D, Kesehatan F, et al. Hubungan pajanan debu dengan kapasitas paru pada pekerja di area boiler PT. Makassar Tene. 2019;2(1):18$24 . \quad$ Available from: https://doi.org/10.30597/jkmm.v2i1.10702

https://journal.unhas.ac.id/index.php/jkmmunhas /article/view/10702/5567

20. Hafsari D, Ramadhian MR, Saftarina F. Debu Batu Bara Dan Kejadian Infeksi Saluran Pernafasan Akut Pada Pekerja Pertambangan Batu Bara. Majority [Internet]. 2015;4(9):35-41. Available from: https://juke.kedokteran.unila.ac.id/index.php/maj ority/article/view/1405/1247

21. Sholihah Q, Hanafi AS, Wanti W, Bachri AA, Hadi S. Analisis Sif Kerja, Masa Kerja, dan Budaya K3 dengan Fungsi Paru Pekerja Tambang Batu Bara. Kesmas Natl Public Heal J [Internet]. 2015 Aug 1;10(1):24. Available from: http://dx.doi.org/10.21109/kesmas.v10i1.812

22. Hall NB, Blackley DJ, Halldin CN, Laney AS. Current Review of Pneumoconiosis Among US Coal Miners. Curr Environ Heal Reports [Internet]. 2019 Sep 13;6(3):137-47. Available from: http://doi.org/10.1007/s40572-019-002375

23. Laney AS, Petsonk EL, Hale JM, Wolfe AL, Attfield MD. Potential determinants of coal workers' pneumoconiosis, advanced pneumoconiosis, and progressive massive fibrosis among underground coal miners in the United States, 2005-2009. Am J Public Health [Internet]. 2012 May;102 Suppl(S2):S279-83. Available from: http://doi.org/10.2105/AJPH.2011.300427

24. Suarthana E, Laney AS, Storey E, Hale JM, Attfield MD. Coal workers' pneumoconiosis in the United States: regional differences 40 years after implementation of the 1969 Federal Coal Mine Health and Safety Act. Occup Environ Med [Internet]. 2011 Dec 1;68(12):908-13. Available from: https://oem.bmj.com/lookup/doi/10.1136/oem.20 10.063594

25. Cohen R, Patel A, Green F. Lung Disease Caused by Exposure to Coal Mine and Silica Dust. Semin Respir Crit Care Med [Internet]. 2008 Dec 16;29(06):651-61. Available from: http://www.thiemeconnect.de/DOI/DOI?10.1055/s-0028-1101275

26. Perret JL, Plush B, Lachapelle P, Hinks TSC, Walter C, Clarke P, et al. Coal mine dust lung disease in the modern era. Respirology [Internet]. 2017 May;22(4):662-70. Available 
from: http://doi.wiley.com/10.1111/resp.13034

27. Stansbury RC. Progressive Massive Fibrosis and Coal Mine Dust Lung Disease: The Continued Resurgence of a Preventable Disease. Ann Am Thorac Soc [Internet]. 2018 Dec;15(12):1394-6. Available

from: https://www.atsjournals.org/doi/10.1513/Annals ATS.201809-598ED

28. Grové T, Van Dyk T, Franken A, Du Plessis J. The Evaluation and Quantification of Respirable Coal and Silica Dust Concentrations: A Taskbased Approach. J Occup Environ Hyg [Internet]. 2014 Jun 3;11(6):406-14. Available from:

https://www.tandfonline.com/doi/full/10.1080/1 5459624.2013.877140

29. J1 A, Churg A, Fh G. Table 1. Thoracic Society of Australia and New Zealand Recommendations for Control of Coal Workers ,
Pneumoconiosis Goal: Eliminate CWP in Australia 1. Exposure limits and monitoring protocols. :773-4.

30. Cui K, Shen F, Han B, Yuan J, Suo X, Qin T, et al. Comparison of the Cumulative Incidence Rates of Coal Workers' Pneumoconiosis between 1970 and 2013 among Four StateOwned Colliery Groups in China. Int J Environ Res Public Health [Internet]. 2015 Jun 30;12(7):7444-56. Available from: http://doi.org/10.3390/ijerph120707444

31. Graber JM. Application of the Delphi method to reduce disability and mortality from coal mine dust lung disease in China; a new approach to an old problem. Occup Environ Med [Internet]. 2018 Sep;75(9):615-6. Available from: https://oem.bmj.com/lookup/doi/10.1136/oemed2018-105075 